\title{
Non-fatal injuries sustained by seatbelt wearers: a comparative study
}

\author{
M S CHRISTIAN
}

British Medical fournal, 1976, 2, 1310-1311

\section{Summary}

The injuries sustained by 969 drivers and front-seat passengers in road-traffic accidents were studied. Altogether $196(20.2 \%)$ of the drivers and passengers were wearing seat belts and $773(79.8 \%)$ were not. The injuries among the two groups differed greatly in both severity and distribution. A total of $54\left(27 \cdot 6^{\circ}\right)$ of the seatbelt wearers sustained one or more fractures compared with $300(38 \cdot 8 \%)$ of the non-wearers, and $18(9 \cdot 2 \%)$ of the seatbelt wearers were severely injured compared with 300 $\left(38.8^{\circ},{ }_{0}\right)$ of the non-wearers. Soft-tissue injuries to the face were sustained by only $29(14.8 \%)$ of the seatbelt wearers compared with $425\left(55^{\circ},{ }_{0}\right)$ of the non-wearers.

Since wearing seatbelts may become compulsory, the type and pattern of injuries to be expected in wearers should be appreciated.

\section{Introduction}

The pattern of injuries sustained in road-traffic accidents by drivers and front-seat passengers not wearing seatbelts is well known, ${ }^{2}$ particularly the often lethal ${ }^{3}$ combination of severe head, facial, and chest injuries. Not so well documented, however, are the type and distribution of injuries sustained when wearing some form of restraint, such as a lapstrap or diagonal belt. ${ }^{4}$ Occasional reports of injuries caused by the seatbelts themselves may be misinterpreted, ${ }^{5}$ and therefore such injuries, particularly visceral injuries caused by the lap component of seatbelts, should be reported whenever they occur.

In this preliminary report I compare the injuries sustained by people wearing seatbelts with those of people not wearing them.

\section{Patients and methods}

A total of 969 patients injured in road-traffic accidents were studied. All had sustained non-fatal injuries and were known to be drivers or front-seat passengers. At the time of the accident 773 $(79.8 \%)$ were unrestrained and $196(20.2 \%)$ were wearing seatbelts. Initially the severity of the injuries was classified without knowing whether the patient had or had not been wearing a seatbelt. Then in both categories the injuries were recorded as either fractures and dislocations or soft-tissue damage alone. The two groups were then compared.

\section{Wexham Park Hospital, Slough, Berks SL2 4HL}

M S CHRISTIAN, MB, FRCS, consultant-in-charge, accident and emergency department
The anatomical distribution of the lesions was noted particularly, and their severity classified as follows: minor-those necessitating admission to hospital for under 48 hours and resulting in less than two weeks away from work or school; moderate-those consisting of one or more fractures and necessitating a stay in hospital, with a return to normal activities after less than two months; and serious-those requiring urgent admission to hospital, often with immediate resuscitation, and which resulted in prolonged disability and time off work.

\section{Results}

Of the 196 patients wearing seatbelts, $141(71.9 \%)$ sustained minor injuries, $37(18.9 \%)$ moderate injuries, and $18(9.2 \%)$ severe injuries. Of the 773 not wearing seatbelts, $444(57.4 \%)$ sustained minor injuries, $208(26.9 \%)$ moderate injuries, and $122(15 \cdot 8)$ severe injuries.

As shown in figures 1 and 2, most of the fractures and dislocations and soft-tissue injuries occurred among those not wearing seatbelts. Although this division of injuries may seem somewhat artificial, since most fractures are associated with some soft-tissue damage, in is logical to assume that more force is required to cause a fracture than to cause only soft-tissue damage.

Average speeds at impact-obtained in 678 cases $(70 \%)$-were $36.3 \mathrm{mph}(58.4 \mathrm{kph})$ in the case of those wearing seatbelts, and $38.1 \mathrm{mph}(61.3 \mathrm{kph})$ in the case of those not wearing them.

\section{SITES OF INJURIES}

Legs-Contrary to Australian reports, ${ }^{6}$ the nature and severity of injuries to the legs did not differ greatly between wearers and nonwearers of seatbelts ${ }^{7}$ (see figs 1 and 2).

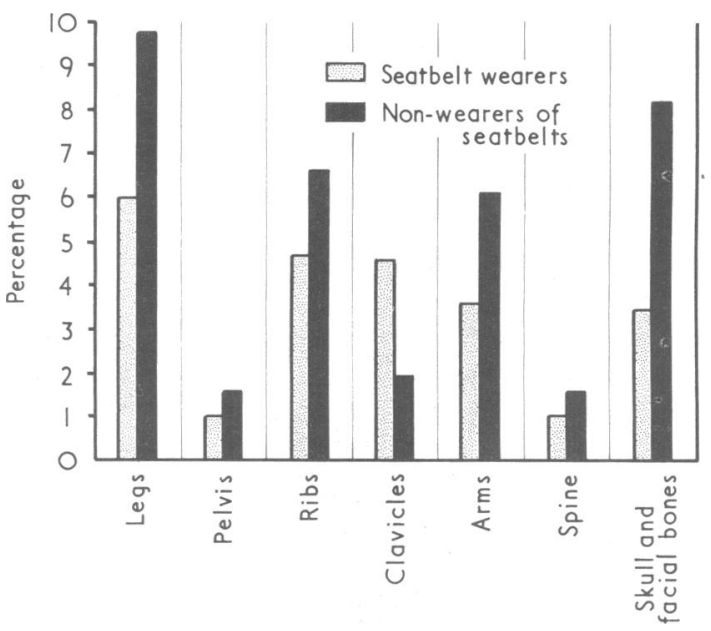

FIG 1-Percentage distribution of fractures and dislocations sustained by wearers and non-wearers of seatbelts. 


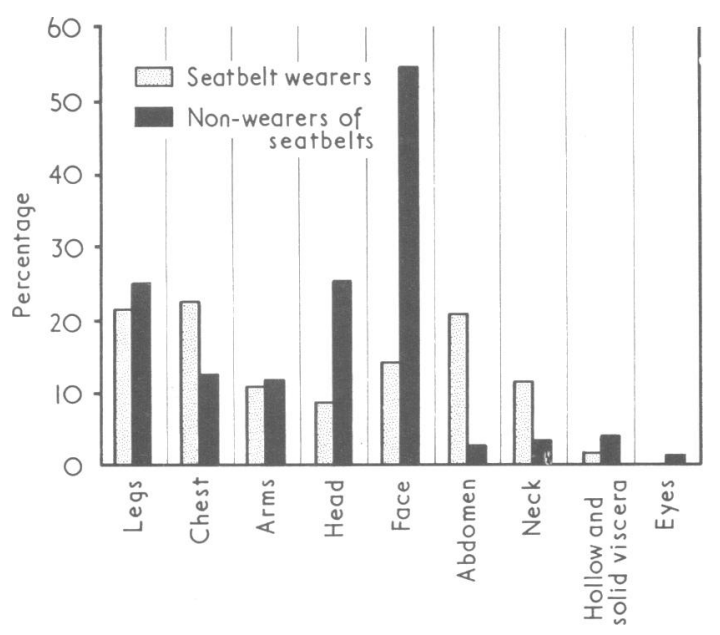

FIG 2-Percentage distribution of soft-tissue injuries sustained by wearers and non-wearers of seat belts.

Chest, ribs, and clavicles-The two groups of patients differed appreciably in injuries to these structures. As would be expected, there were many more soft-tissue injuries with no underlying fractures among the seatbelt wearers, which were due almost entirely to the seatbelts themselves. The typical injury was severe bruising across the chest wall, usually following the line of the seatbelt. There was little difference between the two groups in the proportions with fractured ribs, though a notably large proportion of those not wearing seatbelts had multiple rib fractures, and many had severe fractures of one rib. This type of injury is often associated with severe intrathoracic damage and multiple injuries to the head and chest. Seatbelt wearers with fractured ribs generally had single fractures of the lower ribs on the side nearest the floor anchorage. Fractures of the clavicle were much more common among the seatbelt wearers and without exception occurred where the seatbelt crosses the shoulder girdle. In $2{ }^{\circ}$ of such cases this and bruising of the chest was the only injury.

Arms-Seven of the seatbelt wearers $\left(3.6^{\circ}\right)$ and $47\left(6 \cdot 1^{\circ}\right)$ of the non-wearers sustained fractures of the arms. Front-seat passengers not wearing seatbelts throw out their arms to save themsevles, and unrestrained drivers violently grip the steering wheel at the moment of impact, the equally violent deceleration causing the fractures.

Spine-Spinal injuries were three times more common among nonwearers of seatbelts than among wearers. At impact, non-wearers continue at the speed of the vehicle, the upper trunk, head, and shoulders progressing forward and upwards, presumably acutely flexing over the steering column or through the windscreen or hitting the roof. This acute and violent flexion of the spine is probably responsible for these injuries.

Head and face-Altogether $63(8 \cdot 2 \%)$ of the non-wearers of seatbelts sustained fractures of the skull and facial bones compared with $7(3.5 \%)$ of the wearers, who had fractures of the facial bones only. Soft-tissue damage to the face and scalp ${ }^{8}$ occurs in $79.8^{\circ} \%$ of unrestrained road-traffic accident victims. ${ }^{9}$ In this series, however, only $47(24 \%)$ of the seatbelt wearers had such injuries, which in five cases were relatively minor ones to the chin, ear, and side of the face from the seatbelt itself, possibly due to incorrect adjustment or fitting.

Neck-"Whiplash" injuries to the neck were much more common among the seatbelt wearers than among the non-wearers. This accords with the experience of Gissane ${ }^{10}$ and of some Australian observers, who suggest that head restraints fitted to the front seats would reduce the numbers of such injuries. Although whiplash injuries are rarely associated with fractures of the cervical spine (none occurred in this series), they may result in prolonged disability.

Abdominal wall and abdominal viscera-Soft-tissue damage to the abdominal wall occurred in $20\left(10 \cdot 2^{\circ}{ }_{0}\right)$ of the seatbelt wearers as compared with only $21(2.7 \%)$ of the non-wearers. This preponderance among seatbelt wearers, however, may be expected in view of the restraining function of the lap component of seatbelts. In such cases the damage is often clearly defined and indicates that the lap component has been improperly worn-usually above the iliac crest and sometimes above the waist. Correct positioning of the lap component-namely, firmly opposed to the anterior iliac spines-might dramatically reduce these injuries. ${ }^{10}$ Damage to hollow and solid viscera, on the other hand, was only half as common among the seatbelt wearers. ${ }^{11}$ The incidence of severe injuries to kidney, spleen, and liver, particularly among non-wearers of seatbelts, is almost certainly underestimated, especially in cases of severe multiple injuries. In a separate survey that included fatal accidents some $25 \%$ of injuries to kidney, spleen, and liver found at necropsy had been missed before death. ${ }^{12}$

Eyes-Fourteen of the non-wearers of seatbelts $(18 \%)$ lost one or both eyes or the sight of one or both through penetrating injuries. None of the wearers were so injured.

\section{Comment}

Road-traffic accidents have not appreciably decreased in the past decade, but should the wearing of seatbelts become compulsory the number of serious injuries may fall. Seatbelt wearers, however, are subject to certain injuries that differ from those seen in non-wearers. ${ }^{13}$ Knowledge of the pattern of these injuries is highly relevant in diagnosis and management.

The results of this study suggest that wearing seatbelts would reduce the number of serious chest injuries and the number and severity of rib injuries but increase the number of fractured clavicles. Arms would also be less vulnerable. The most noticeable effect, however, would be fewer severe head injuries, particularly facial mutilation. Whiplash injuries to the neck would probably increase unless systems for head and neck restraint were introduced. ${ }^{14}$

Compulsory wearing of seatbelts would probably be insufficient in itself to ensure fewer injuries to solid and hollow intra-abdominal viscera. Steps should be taken to standardise the type of seatbelts used and ensure that they are worn correctly. ${ }^{15}$ Then some of the injuries still unacceptably common among seatbelt wearers might be reduced.

I thank Mr D Wadbrook, computer manager, Royal Free Hospital, Hampstead, for advice and technical help in preparing this article, and Miss Valerie Johnston for preparing the material contained in it.

\section{References}

${ }^{1}$ British Medical fournal, 1969, 4, 63.

2 British Medical fournal, 1973, 1, 370

${ }^{3}$ British Medical fournal, 1974, 2, 624.

4 British Medical fournal, 1973, 2, 195.

${ }^{5}$ Jolles, K E, British Medical fournal, 1974, 1, 119

6 Rank, B J, 1975, personal communication.

7 Grattan, E, and Hobbs, J A, British Medical fournal, 1969, 1, 71.

8 Daily Telegraph, 17 March 1973, letter to the editor.

9 Schultz, R C, Plastic and Reconstructive Surgery and Transplantation Bulletin, 1967, 40, 415 .

Tang, O T, Mir, A, and Delamore, I W, British Medical fournal, 1974, 4, 750.

${ }_{11}$ British Medical fournal, 1974, 1, 85.

12 Gissane, W, and Bull, J, British Medical fournal, 1971, 1, 270.

${ }^{13}$ Brooks, S H, Nahum, A M, and Swiegel, A W, Surgery, Gynecology and Obstetrics, 1970, 131, 185.

14 Gissane, W, British Medical fournal, 1972, 2, 288.

15 Wilks, P M, Proceedings of the Royal Society of Medicine, 1967, 60, 955.

Would a prick test through a drop of antisnake serum on the skin be of value as a test for sensitivity to horse serum for someone in the bush who urgently needs treatment for snake bite?

No, because (1) antivenom is indicated only in victims with serious poisoning (and is not indicated in victims with little or no poisoning, who form the majority); (2) if antivenom were indicated it has to be given intravenously to be effective and, generally speaking, this could be done only in hospital; and (3) when antivenom is indicated, serum sensitivity tests are not recommended as they are often misleading. Reactions may occur despite negative test results, sometimes owing to complement activation. Moreover, in some severe cases, with a positive test reaction, intravenous antivenom has been subsequently infused with no reaction. ${ }^{1}$

${ }^{1}$ Reid, H A, British Medical fournal, 1976, 2, 153. 